Utah State University

DigitalCommons@USU

1988

\title{
Breeding birds in uncut aspen and 6- to 10-year-old clearcuts in southwestern Colorado
}

V.E. Scott

G.L. Crouch

Follow this and additional works at: https://digitalcommons.usu.edu/aspen_bib

Part of the Forest Sciences Commons

\section{Recommended Citation}

Scott, V.E. and Crouch, G.L., "Breeding birds in uncut aspen and 6- to 10-year-old clearcuts in southwestern Colorado" (1988). Aspen Bibliography. Paper 3285.

https://digitalcommons.usu.edu/aspen_bib/3285

This Article is brought to you for free and open access by the Aspen Research at DigitalCommons@USU. It has been accepted for inclusion in Aspen Bibliography by an authorized administrator of DigitalCommons@USU. For more information, please contact

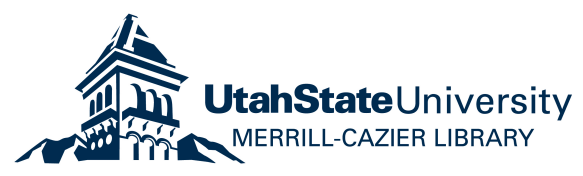



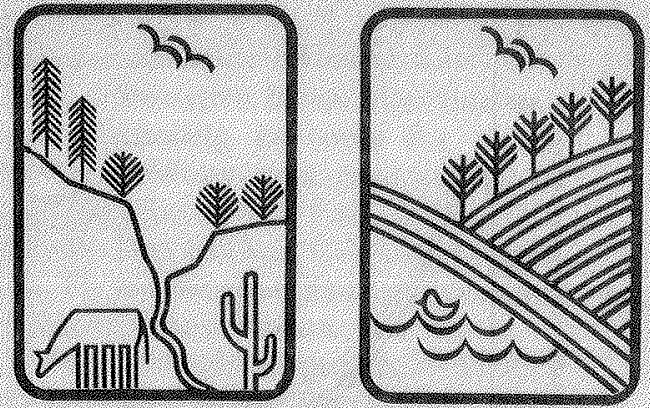

Research Note RM-485

March 1988

USDA Forest Service

Rocky Mountain Forest and Range Experiment Station

\title{
Breeding Birds in Uncut Aspen and 6- to 10-Year-Old Clearcuts in Southwestern Colorado
}

\author{
Virgil E. Scott ${ }^{1}$ and Glenn L. Crouch ${ }^{2}$
}

\begin{abstract}
Numbers of breeding birds were estimated for various sizes and ages of clearcuts, for edge habitat created by the clearcuts, leave strips between clearcuts, and uncut aspen forest (controls). Total numbers of birds were not different among three size classes or five age classes of clearcuts. Totals were lower on clearcuts than on edges but not different from controls or leave strips.
\end{abstract}

Keywords: aspen, clearcutting, birds

\section{Introduction}

Aspen (Populus tremuloides) is the only commercially important nonconiferous tree species in the central Rocky Mountains. Although aspen has had little market potential in the West, demand is increasing. About 4 million acres of commercial aspen occur within the Rocky Mountain region; 3 million acres are in Colorado (Wengert 1976).

In the western United States, aspen is a component of many forest types; as the predominant species, it rarely covers extensive areas, except in Colorado and Utah (Daniel 1979). The importance of aspen communities for birds has been documented by Flack (1976), Salt (1957), and Winternitz (1976).

Aspen normally reproduces vegetatively by root suckers in stands that have been opened by fire, windthrow, or cutting (DeByle 1976). It is intolerant of shade; regeneration may be inhibited by leaving trees standing after harvest. Aspen commonly is harvested by clearcutting, which usually promotes regeneration by suckering. DeByle (1981) reported an increase in the number of bird species but decreases in the total number of individuals after clearcutting on a 10-acre plot in Utah, but little other information has been published regarding bird response to commercial clearcutting of aspen in the West.

\footnotetext{
1 Research Wildife Biologist, Retired, Denver Wildilte Research Center, Ecology Branch, Fort Collins, Colo.

${ }^{2}$ Research Wildlife Blologist, Rocky Mountain Forest and Range Experiment Station. Headquarters is in Fort Collins, in cooperation vith Colorado State University.
}

We therefore compared bird densities in different clearcut size-classes, among five clearcut age classes, with those in habitats along the edges of clearcuts, strips of habitat between clearcuts, and uncut aspen. An earlier, less detailed paper described avian activity on the same study area 1 to 5 years after the clearcut harvest (Scott and Grouch 1987).

\section{Study Area}

The study area was located in the West Stoner aspen sale area (a mosaic of aspen forest with clearcuts) on the Dolores District of the San Juan National Forest, 25 miles northeast of Dolores, Colo. Elevations range from 9,000 to 10,000 feet, and topography is mostly gentle. The site is occupied by a nearly pure stand of mature aspen (Crouch 1983). Small meadows ( $10 \%$ of the area) are interspersed throughout. Aspen was clearcut in patches ranging from 3 to 20 acres, from 1974 through 1978. About 600 acres ( $25 \%$ of the sale area) were harvested, mostly in 1977 and 1978. Subalpine fir (Abies lasiocar$\mathrm{pa}$ ) and Engelmann spruce (Picea engelmannii) trees composed about $1 \%$ of the stands before logging, and those within the clearcuts were left standing.

\section{Methods}

Numbers of breeding birds were estimated in four overstory categories, including various sizes and ages 
of clearcuts, edge habitat created by clearcuts, leave strips between clearcuts, and uncut forest. To inventory birds, we used a point-count technique with a fixed observation radius of 100 feet. One point-count plot was established at the center of each of 30 clearcuts; 10 in each of three size classes (small $\bar{x}=4.4$ acres \pm 0.4 , medium $\bar{x}=8.9$ acres \pm 0.6 , and large $\bar{x}=14.1$ acres \pm 1.0 ). Two of the 10 harvests in each of the three size classes had been cut each winter from 1974-75 to 1978-79.

One point-count plot, half in the clearcut and half in aspen, was established at the edge of each clearcut, and $\geqslant 100$ feet from the clearcuts in the adjacent leave strips. Thirty point-count plots also were established in uncut aspen stands outside the sale area to serve as controls. Birds were counted twice on all plots between June 12 and July 2, 1984, between sunrise and 3 hours after sunrise. Differences $(P=0.05)$ among overstory categories, and size and age of clearcuts were compared with analysis of variance, using the number of individual birds observed at each plot as one observation. Differences among overstory categories were tested with a Newman-Keuls test (Snedecor and Cochran 1980). Statistics were computed using MUSTAT (Lund 1985). Species of birds observed beyond the 100 -foot radius, and those with few observations and not included in the density estimates, are indicated by an asterisk in appendix 1 .

Diversity profiles for birds were prepared following Patil and Taillie (1979). They were interpreted using the criterion that lines in the profile that are separated and do not cross indicate a difference in diversity, whereas those lines that are close together or cross indicate no difference.

\section{Results and Discussion}

\section{Clearcut Age and Size Class Comparisons}

Solitary vireos ${ }^{3}$ were more numerous on the 10 -yearold clearcuts than on 6-, 7-, and 8-year-old clearcuts (table 1). No differences were detected for any other individual bird species among age or size class of clearcuts (tables 1 and 2). Hermit thrushes, which usually inhabit mature forests (Szaro and Balda 1979), were counted on the 9and 10-year-old but not on the younger clearcuts. Total bird densities were not different among age or size classes of clearcuts.

\section{Clearcut, Edge, Leave Strip, and Control Comparisons}

Song sparrows and white-crowned sparrows prefer forest edges, clearings, or low brushy fields (Udvardy 1977), and were more numerous on the clearcuts and edges than on controls or leave strips (table 3). Broadtailed hummingbirds also were more numerous in clearcuts than on sites in other overstory categories. Numbers of solitary vireos, which inhabited the older-age clear-

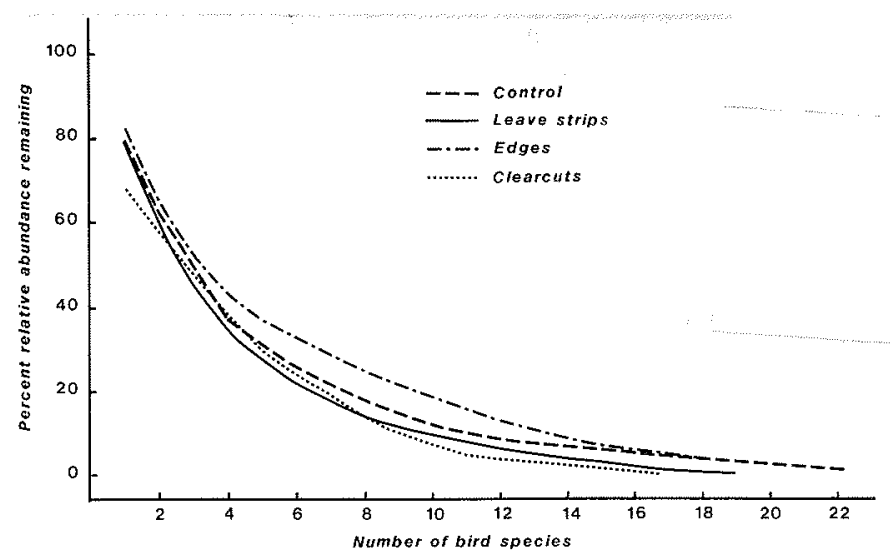

Figure 1.-Species diversity profile of bird communities in controls, leave strips, edges, and clearcuts, Stoner Mesa, Colo.

cuts, were not different among overstory categories. Total bird density was higher on edge habitat than on clearcuts, but not different from controls or leave strips.

Fewer cavity-nesting birds were observed on clearcuts ( $6 \%$ of birds), compared with controls ( $33 \%$ ), leave strips (34\%), and edges (39\%). Although house wrens were the most numerous cavity nesters on clearcuts (they sometimes nest in slash/brushpiles or fallen trees with holes (Thomas 1979)], they were still less numerous on clearcuts than on leave strips and controls. In this study, swallows (violet-green and tree) were recorded only when perched, even though many swallows were observed foraging above the clearcuts. More swallows were recorded at edges than in other habitats. At edges, swallows usually perched or nested in dead aspen trees. Purple martins also foraged above clearcuts, and several were observed while perched in trees near the clearcuts but beyond the 100 -foot sampling radius.

Fewer yellow-rumped warblers and warbling vireos (birds that nest and feed in the canopy) were counted on clearcuts than in other overstory habitats. Numbers of yellow-rumped warblers and warbling vireos were not different among controls, leave strips, or edges, but MacGillivray's warblers, which are usually found in shrubby habitats, were not seen on the controls.

The diversity profile (fig. 1) indicated that bird diversity was greater on edge habitat ( 23 species) than on clearcuts (17 species) or leave strips (19 species). The diversity between edges and controls (23 species) was not different, but the measure of evenness (as indicated by the diversity profile) was greater for edges, at least among 16 of the most abundant species.

\section{Conclusions}

Effects of clearcutting on bird abundance and composition in aspen appear to be temporary if regeneration is prompt. Within 10 years, for example, saplings in the older clearcuts provided habitat for hermit thrushes, which usually are associated with mature forests. Birds such as broad-tailed hummingbirds, solitary vireos, and song and white-crowned sparrows were more numerous on the clearcuts than on the controls or leave strips, but 
Table 1.-Mean densities (no./100 acres) and standard error (S.E.) of birds according to year classes of clearcuts, Stoner Mesa, Colo. ${ }^{1}$

\begin{tabular}{lccccc}
\hline & \multicolumn{5}{c}{$\begin{array}{c}n=6 \\
\text { Years after cutting }\end{array}$} \\
\cline { 2 - 6 } & $\mathbf{1 0}$ & $\mathbf{9}$ & $\mathbf{8}$ & $\mathbf{7}$ & $\mathbf{6}$ \\
\hline Broad-tailed hummingbird & 12 & 23 & 46 & 0 & 46 \\
& $(12)$ & $(12)$ & $(31)$ & $(0)$ & $(23)$ \\
House wren & 0 & 12 & 12 & 12 & 0 \\
& $(0)$ & $(12)$ & $(12)$ & $(12)$ & $(0)$ \\
Hermit thrush & 35 & 23 & 0 & 0 & 0 \\
American robin & $(20)$ & $(12)$ & $(0)$ & $(0)$ & $(0)$ \\
& 23 & 12 & 0 & 0 & 36 \\
Solitary vireo & $(23)$ & $(12)$ & $(0)$ & $(0)$ & $(36)$ \\
MacGillivray's warbler & $58 \mathrm{a}$ & $46 \mathrm{ab}$ & $0 \mathrm{c}$ & $12 \mathrm{~b}$ & $0 \mathrm{c}$ \\
& $(11)$ & $(23)$ & $(0)$ & $(12)$ & $(0)$ \\
Song sparrow & 12 & 12 & 23 & 0 & 12 \\
White-crowned sparrow & $(12)$ & $(12)$ & $(23)$ & $(0)$ & $(12)$ \\
Dark-eyed junco & 23 & 81 & 116 & 104 & 58 \\
& $(23)$ & $(31)$ & $(12)$ & $(20)$ & $(42)$ \\
Other birds & 0 & 23 & 23 & 35 & 46 \\
Total & $(0)$ & $(12)$ & $(20)$ & $(12)$ & $(23)$ \\
& 0 & 23 & 35 & 12 & 23 \\
& $(0)$ & $(23)$ & $(20)$ & $(0)$ & $(31)$ \\
& 69 & 35 & 23 & 12 & 12 \\
& $(40)$ & $(20)$ & $(12)$ & $(12)$ & $(12)$ \\
& 232 & 290 & 278 & 187 & 233 \\
& $(31)$ & $(61)$ & $(53)$ & $(12)$ & $(76)$ \\
\hline
\end{tabular}

${ }^{1}$ Within species, means followed by no letter or the same letter are not different $(P=0.05)$.

Table 2.-Mean densities (no./100 acres) and standard error (S.E.) of estimated birds according to size classes of clearcuts, Stoner Mesa, Colo. ${ }^{1}$

\begin{tabular}{lccc}
\hline & & $n=10$ & \\
\cline { 2 - 4 } & Small & Medium & Large \\
\hline Broad-tailed hummingbird & 7 & 35 & 35 \\
& $(7)$ & $(11)$ & $(22)$ \\
House wren & 7 & 0 & 14 \\
& $(7)$ & $(0)$ & $(9)$ \\
Hermit thrush & 0 & 21 & 14 \\
& $(0)$ & $(14)$ & $(9)$ \\
American robin & 21 & 21 & $(0)$ \\
& $(14)$ & $(21)$ & 21 \\
Solitary vireo & 21 & 28 & $(14)$ \\
& $(14)$ & $(17)$ & 0 \\
MacGillivray's warbler & 21 & 14 & $(0)$ \\
& $(14)$ & $(9)$ & $(21)$ \\
Song sparrow & 104 & 76 & 28 \\
& $(22)$ & $(25)$ & $(11)$ \\
White-crowned sparrow & 7 & 21 & 35 \\
Dark-eyed junco & $(7)$ & $(14)$ & $(11)$ \\
& 21 & 14 & 35 \\
Other birds & $(21)$ & $(14)$ & $(27)$ \\
Total & 28 & 28 & 230 \\
& $(22)$ & $(13)$ & $(40)$ \\
\hline
\end{tabular}

${ }^{1}$ Within species, means followed by no letter or the same letter are not different $(P=0.05$ ). 
Table 3. - Mean densities of birds (no./100 acres) with standard error (S.E) on the Stoner Mesa, Colo.

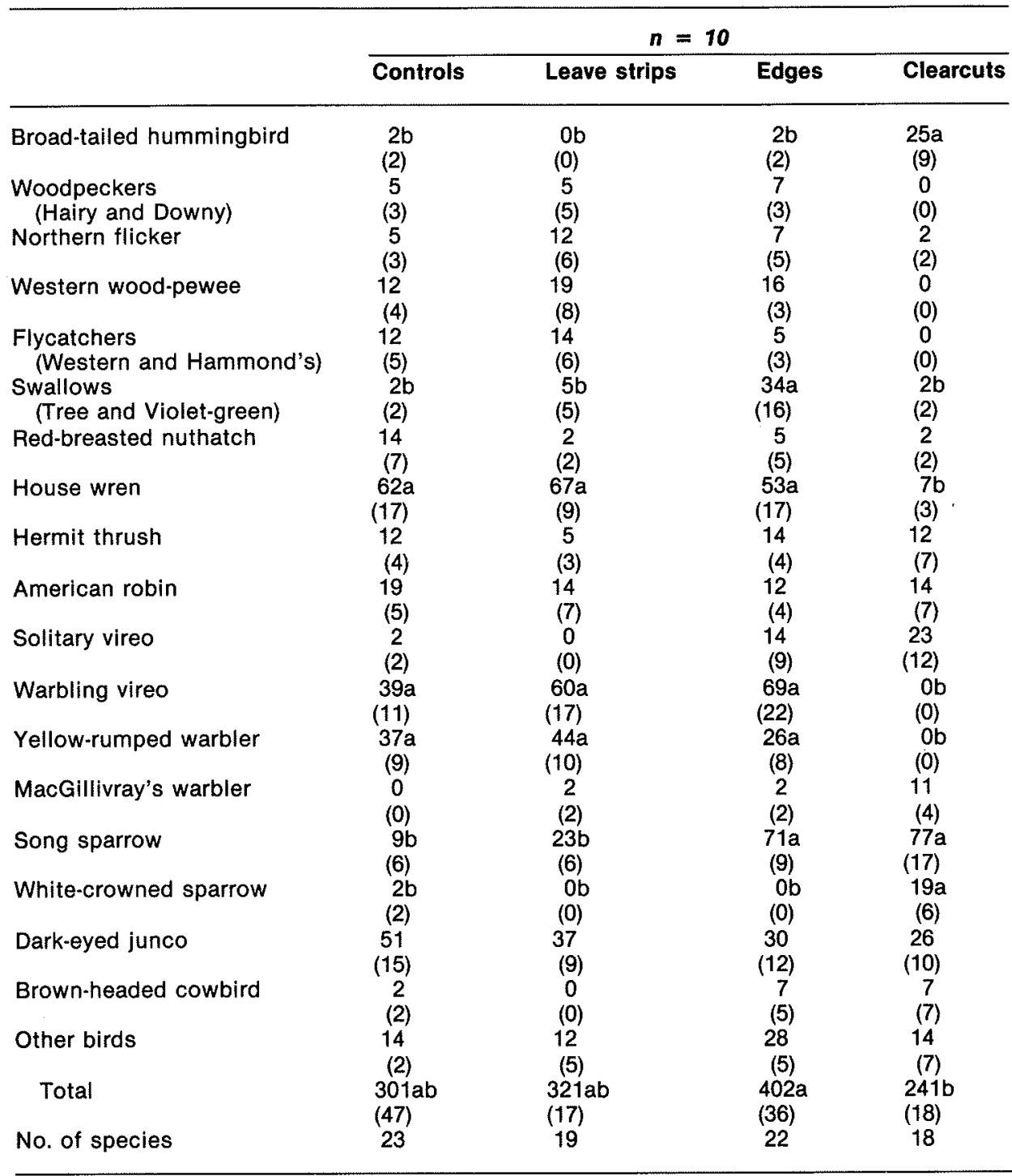

${ }^{1}$ Within species, means followed by no letter or the same letter are not different $(P=0.05)$.

total bird density was not different among these three overstory categories. Total bird density was higher on edges than in clearcuts, but not different from the other categories.

Cavity-nesting birds, specifically swallows and house wrens, were less numerous on clearcuts than in other habitats, as were yellow-rumped warblers and warbling vireos. Birds that prefer early successional stages, such as broad-tailed hummingbirds, MacGillivray's warblers, song sparrows, and white-crowned sparrows, should increase in numbers within clearcuts, especially after aspen regeneration is established.

Periodic clearcutting of aspen in relatively small blocks over a span of years in the same area should provide a mosaic of age classes, and could result in increased local bird diversity. The sample size for this study was limited by the availability of clearcuts by size and age class. Birds that occupy large territories and less common birds were not sampled in numbers sufficient to determine their response to the small patch clearcutting. It is possible that raptors and other birds that require extensive stands of mature forests could have been adversely affected. Downy woodpeckers, for instance, were observed in the leave strips, but hairy woodpeckers were observed only on the controls.

\section{Literature Cited}

Crouch, Glenn L. 1983. Aspen regeneration after commercial clearcutting in southwestern Colorado. Journal of Forestry 83: 316-319.

Daniel, T. W. 1979. The middle and southern Rocky Mountain region. In: Barrett, John W., ed. Regional silviculture of the United States. New York, NY: John Wiley and Sons: 277-340. 
DeByle, Norbert V. 1976. The aspen forest after harvest. In Utilization and marketing as tools for aspen management in the Rocky Mountains: proceedings of the symposium; 1976 September 8-9; Fort Collins, CO. Gen. Tech. Rep. RM-29. Fort Collins, CO: U.S. Department of Agriculture, Forest Service, Rocky Mountain Forest and Range Experiment Station: 35-40.

DeByle, Norbert V. 1981. Songbird populations and clearcut harvesting of aspen in northern Utah. Res. Note INT-302. Ogden, UT: U.S. Department of Agriculture, Forest Service, Intermountain Forest and Range Experiment Station. 7 p.

Flack, J. A. Douglas. 1976. Bird populations of aspen forests in western North America. American Ornithological Union, Ornithological Monographs No. 19. $97 \mathrm{p}$.

Lund, Richard E. 1985. Mustat-an interactive statistical analysis package. Montana State University, Bozeman, MT. $123 \mathrm{p}$.

Patil, G. P.; Taillie, C. 1979. A study of diversity profiles and orderings for a bird community in the vicinity of Colstrip, Montana. In: Patil, G. P.; Rosenzweig, M., eds. Contemporary quantitative ecology and related econometrics. Fairland, MD: International Cooperative Publishing House: 23-48.

Salt, George William. 1957. An analysis of avifaunas in the Teton Mountains and Jackson Hole, Wyoming. Condor 59: 373-393.

Scott, Virgil E.; Crouch, Glenn L. 1987. Response of breeding birds to commercial clearcutting of aspen in southwestern Colorado. Res. Note RM-475. Fort Collins, CO: U.S. Department of Agriculture, Forest Service, Rocky Mountain Forest and Range Experiment Station. 5 p.

Snedecor, George W.; Cochran, William G. 1980. Statistical methods. 7th ed. Ames, IA: Iowa State University Press. 507 p.

Szaro, Robert C.; Balda, Russell P. 1979. Bird community dynamics in a ponderosa pine forest. Cooper Ornithological Society, Studies in Avian Biology No. 3. $66 \mathrm{p}$.

Thomas, Jack Ward, tech. ed. 1979. Wildlife habitats in managed forests of the Blue Mountains of Oregon and Washington. Agric. Handbk. 553. Washington, DC: U.S. Department of Agriculture, Forest Service. $512 \mathrm{p}$.

Udvardy, Miklos D. F. 1977. The Audubon Society field guide to North American birds (western region). New York, NY: Alfred A. Knopf. 855 p.

Wengert, Eugene M. 1976. Perspectives on Rocky Mountain aspen resource: An overview. In: Utilization and marketing as tools for aspen management in the Rocky

Mountains: proceedings of the symposium; 1976 September 8-9; Fort Collins, CO. Gen. Tech. Rep. RM-29. Fort Collins, CO: U.S. Department of Agriculture, Forest Service, Rocky Mountain Forest and Range Experiment Station: 2-5.

Winternitz, Barbara A. 1976. Temporal change and habitat preferences of some montane breeding birds. Condor 78: 383-393.

\section{Appendix 1}

Common and scientific names of all birds observed on the Stoner Mesa study site. Nomenclature follows the check-ist of North American birds, sixth edition, 1983. Birds with an asterisk were observed at distances greater than 100 feet and are not included in density estimates.

Bird

Green-winged teal ${ }^{*}$ Red-talled hawk* Broad-tailed hummingbird Yellow-bellied sapsucker ${ }^{*}$ Downy woodpecker Hairy woodpecker Northern flicker Olive-sided flycatcher* Western wood-pewee* Hammond's flycatcher Western flycatcher Purple martin*

Tree swallow Violet-green swallow Gray jay*

Steller's jay*

Common raven*

Mountain chickadee *

Red-breasted nuthatch

House wren

Ruby-crowned kinglet*

Mountain bluebird*

Hermit thrush

American tobin

Warbling vireo

Solitary vireo

Yellow-rumped warbler

MacGillivray's warbler

Western tanager*

Green-tailed towhee*

Chipping sparrow*

Song sparrow

White-crowned sparrow

Dark-eyed junco

Red-winged blackbird*

Brewer's blackbird*

Brown-headed cowbird

Cassin's finch*

Red-crossbill*

Pine siskin*
Anas crecca

Buteo jamaicensis Selasphorus platycercus Sphyrapicus varius Plcoides pubescens Picoides villosus Colaptes auratus Contopus borealis Contopus sordidulus Empidonax hammondii E. difficilis Progne subis Tachycineta bicolor T. thalassina Perisoreus canadensis Cyanocitta stelleri Corvus corax Parus gambeli Sitta canadensis Troglodytes aedon Regulus calendula Sialia currucoides Catharus guttatus Turdus migratorius Vireo gilvus V. solitarius Dendroica coronata oporornis tolmiei Piranga ludoviciana Pipilo chlorurus Spizella passerina Melospiza melodia Zonotrichia leucophrys Junco hyemalis Agelaius phoeniceus Euphagus cyanocephalus Molothrus ater Carpodacus cassinii Loxia curvirostra Carduelis pinus 